\title{
Artemia salina as a model organism in toxicity assessment of nanoparticles
}

Somayeh Rajabi ${ }^{1}$, Ali Ramazani ${ }^{1,2^{*}}$, Mehrdad Hamidi ${ }^{3}$ and Tahereh Naji

\begin{abstract}
Background: Because of expanding presence of nanomaterials, there has been an increase in the exposure of humans to nanoparticles that is why nanotoxicology studies are important. A number of studies on the effects of nanomatrials in in vitro and in vivo systems have been published. Currently cytotoxicity of different nanoparticles is assessed using the 3-(4,5-dimethylthiazol-2-yl)-2,5-diphenyltetrazolium bromide (MTT) assay on different cell lines to determine cell viability, a tedious and expensive method. The aim of this study was to evaluate the Artemia salina test in comparison with the MTT assay in the assessment of cytotoxicity of nanostructures because the former method is more rapid and convenient and less expensive.

Methods: At the first stage, toxicity of different nanoparticles with different concentrations $(1.56-400 \mu \mathrm{g} / \mathrm{mL})$ was measured by means of the brine shrimp lethality test. At the second stage, the effect of nanoparticles on the viability of the L929 cell line was assessed using the MTT assay. Experiments were conducted with each concentration in triplicate.

Results: The results obtained from both tests (A. salina test and MTT assay) did not have statistically significant differences $(P>0.05)$.

Conclusions: These findings suggest that the A. salina test may expedite toxicity experiments and decrease costs, and therefore, may be considered an alternative to the in vitro cell culture assay.
\end{abstract}

Keywords: Artemia salina, Toxicity, Nanoparticle, Cell culture

\section{Background}

Nanoscience is a novel science that is being developed to probe and manipulate matter on the scale of single atoms and molecules. Physicist Richard P. Feynman was the first to mention molecular machines built with atomic precision at a meeting of the American Physical Society in 1959 [1], and Noro Taniguchi, a professor at the University of Tokyo, coined the term nanotechnology in 1979 [2]. Nanotechnology is the use of nanoscience to design NMs (nanomaterials) and NPs (nanoparticles), with structural components between 1 and 100 nanometers; it is thought to be one of the key technologies of the 21st century $[3,4]$. In the above range, physicochemical characteristics of NPs in biological systems can vary. Some potential hazards have been identified in the life cycle

\footnotetext{
* Correspondence: ramazania@zums.ac.ir

'Cell and Molecular Biology Departments, Pharmaceutical Sciences Branch,

Islamic Azad University, Tehran, Iran

${ }^{2}$ Biotechnology Departments, School of Pharmacy, Zanjan University of

Medical Sciences, Zanjan, Iran

Full list of author information is available at the end of the article
}

of NMs and NPs [5,6]. Growing research and development in nanotechnology have resulted in the identification of many unique properties of nanomaterials such as enhanced magnetic, catalytic, optical, electrical, and mechanical properties when compared to conventional formulations of the same materials [7]. While nanoparticles have a wide variety of functions, there has been increasing issues and debate amongst the regulatory and scientific community regarding the fate of nanoparticles in biological systems and associated side effects these agents might have on living organisms [8-12]. These materials are increasingly used for commercial purposes and leading to direct and indirect exposure of humans [13]. Any in vivo use of nanoparticles requires thorough understanding of the kinetics and toxicology of the particles, establishment of principles and test procedures to ensure safe manufacture and usage of nanomaterials, and comprehensive training of personnel in safety and potential hazards of nanotechnology [13]. Nanotoxicology research is applied 
to various fields including biology and pathology, but typically to pharmacology and to the use of NMs and nanodevices for diagnostic and therapeutic purposes. Therefore, a key goal for toxicologists is to identify in vitro and in vivo assays accurately reflecting the ability of NPs to induce toxic effects in the humans and in the environment. In addition, standardized tests for both in vitro and in vivo studies are needed to develop better and more rapid screening techniques and to predict toxicity $[14,15]$. The cytotoxicity effects of NPs were investigated in a multitude of animal models by means of in vivo tests employing the typical NP exposure routes, i.e., pulmonary, oral, dermal, and injection based [16]. The cost and labor intensiveness of the in vivo studies have led researchers to the use of in vitro methods for assessment of NPs cytotoxicity. In addition, animal rights advocates have criticized the use of animals in nanotechnology experiments. All in vivo studies must be conducted with the approval of regulatory bodies such as IACUC (an Institutional Animal Care and Use Committee) to ensure ethical treatment of animals [16]. For the above reasons, in vitro techniques are increasingly used for the analysis of cytotoxicity of NPs including cell culture, the WST- 1 assay [17,18], XTT assay, MTT assay $[19,20], \mathrm{LDH}$ assay, BrdU assay, and fluorescence microscopy [21,22]. Currently, cytotoxicity testing of various NPs in cell culture involves the MTT assay, which determines cell viability based on mitochondrial function by measuring the activity of mitochondrial enzymes [23-27]. In this test, tetrazolium is reduced by mitochondrial succinate dehydrogenase of live cells to water-insoluble purple formazan crystals, which are subsequently solubilized using an organic solvent (e.g., dimethyl sulfoxide; DMSO) [28]. The cell viability is quantified based on absorbance of the solution at $570 \mathrm{~nm}$. Therefore, the MTT assay requires solubilization steps with tetrazolium, which is toxic to cells and can interfere with some chemical reactions [28]. The cytotoxicity assays are often tedious and expensive, and there is a lack of a simple and rapid screening procedure. Nowadays, brine shrimp lethality assays are extensively used in research and applied toxicology [29]. There is a tendency to use an Artemia salina assay in toxicological tests that screen a large number of extracts for drug discovery in medicinal plants [30-33]. This is because in this case, aseptic techniques are not required, and thus $A$. salina assays could replace the more ethically challenging MTT assay that requires animal serum [34]. This assay was proposed by Michael and coworkers in 1959 and was later adopted by many laboratories as a method for preliminary estimation of toxicity [35]. Artemia is one of the most valuable test organisms available for ecotoxicity testing, and the available research suggests that several applications of Artemia to toxicology and ecotoxicology will continue to be used widely [36]. Because of the rapidity, convenience, and low cost of Artemia-based assays, we decided to evaluate the A. salina test in comparison with the MTT assay in the assessment of cytotoxicity of different classes of NPs.

\section{Materials and methods \\ Materials}

Fetal bovine serum (FBS), phosphate-buffered saline (PBS), trypsin, penicillin, streptomycin, DMSO, 3-[4,5-dimethylthiazol-2-yl]-2,5-diphenyl tetrazolium bromide (MTT), Triton X-100, and the RPMI-1640 medium supplemented with $10 \%$ heat inactivated FBS were purchased from Sigma-Aldrich. The mouse fibroblast cell line (L929) was provided by Pasteur Institute of Iran.

\section{Synthesis of NPs}

Sixteen NPs from different classes (Table 1) were prepared by the Nanotechnology Laboratory of School of Pharmacy of Zanjan University of Medical Sciences. The zeta potential and particle size distribution of the prepared nanoparticles were determined by photon correlation spectroscopy (PCS) using a Nano/zetasizer (Malvern Instruments, Nano ZS, Worcestershire, UK) working on the dynamic light scattering (DLS) platform.

\section{Cell culture and determination of cytotoxicity by MTT assay}

The effect of NPs on the viability of L929 cells was assessed by means of the MTT assay. After thawing, the cells were cultured in the RPMI 1640 medium containing 10\% FBS, penicillin (100 units $/ \mathrm{mL}$ ), and streptomycin $(100 \mathrm{mg} / \mathrm{mL})$ at $37^{\circ} \mathrm{C}$ in a humidified $5 \% \mathrm{CO}_{2}$ incubator. The cells were seeded in a 96-well plate at a density of 5,000 cells per well (the cells were stained with trypan blue and counted with haemocytometer). These cells were incubated overnight at $37^{\circ} \mathrm{C}$ before the cell viability test. A stock suspension of each NP at $50 \mathrm{mg} / \mathrm{mL}$ in distilled water was prepared. After that, fresh suspensions of different concentrations of NPs (two fold serial dilutions from $1.56-400 \mu \mathrm{g} / \mathrm{mL}$ ) were made using serial dilution of the stock suspensions of NPs in the RPMI 1640 medium, immediately before use. We added $200 \mu \mathrm{L}$ of a suspension (different concentrations of NPs) to each well of the microtiter plates. The cells were incubated for $24 \mathrm{~h}$ under the same conditions. Wells without any NPs served as a negative control. The experiments were performed in triplicate for each concentration. To assess cell survival, $100 \mu \mathrm{L}$ of an MTT solution (2 $\mathrm{mg} / \mathrm{mL}$ in PBS) was added to each well and incubated for $3 \mathrm{~h}$ at $37^{\circ} \mathrm{C}$ to produce insoluble formazan. Then, $100 \mu \mathrm{L}$ of DMSO was added to dissolve formazan crystals, and the absorbance was measured on an Infinite M200 microplate reader (Tecan) at $570 \mathrm{~nm}$, with $630 \mathrm{~nm}$ as a reference wavelength. The percentage of cell viability 
Table 1 Names and characteristics of NPs used in this study

\begin{tabular}{|c|c|c|c|}
\hline NPs class & NPs name & Size NPs (nm) & Zeta potential $(\mathrm{mV})$ \\
\hline \multirow[t]{2}{*}{ Inorganic nanoparticles } & Magnetic & 55 & -31 \\
\hline & Nanosfer & 97 & +8.9 \\
\hline \multirow[t]{4}{*}{ Lipid-base nanoparticles } & Liposome & 139.3 & -28 \\
\hline & Coated SLNs & 464.6 & +20 \\
\hline & Uncoated SLNs & 176.3 & -45 \\
\hline & Nanogele + SLN & 376.6 & +4 \\
\hline \multirow[t]{5}{*}{ Polymeric nanoparticles } & Nanogele & 270 & +22 \\
\hline & Micellar & 97.9 & -1.10 \\
\hline & PAMAM (G5) & 6 & +36.8 \\
\hline & PAMAM-FA & 55 & +36.4 \\
\hline & PAMAM-PEG-FA & 70 & 9.12 \\
\hline \multirow[t]{5}{*}{ Drug nanoparticles } & Nanosuspansion Atorvastatin & 269.8 & ND \\
\hline & Nanosuspansion Ibuprofen & 160.9 & ND \\
\hline & Nanosuspansion Repaglinide & 260.6 & ND \\
\hline & Nanosuspansion Cyclosporin & 220.5 & ND \\
\hline & Nanosuspansion Azitromycin & 270 & ND \\
\hline
\end{tabular}

ND; not determined.

was calculated using the formula $\left(A_{\text {test }} / A_{\text {control }}\right) \times 100$, where $A_{\text {test }}$ is the mean absorbance of treated cells and $\mathrm{A}_{\text {control }}$ is the mean absorbance of a negative control.

\section{Toxicity testing by $A$. salina}

A. salina eggs were purchased from the Aquatic Animal Research Center, Urmia University, Urmia, Iran. Dried cysts were placed in a bottle containing artificial sea water which was prepared by dissolving $35 \mathrm{~g}$ of sodium chloride in $1 \mathrm{~L}$ of distilled water. After 36-48 h incubation at room temperature $\left(28-30^{\circ} \mathrm{C}\right)$ under conditions of strong aeration and continuous illuminations [33], the larvae (nauplii) hatched within $48 \mathrm{~h}$.

The evaluation of cytotoxicity of NPs in A. salina was performed according to the previous methods [30,33,37,38]. The assay was carried out on larvae of brine shrimp (A. salina Leach.). A stock solution of $50 \mathrm{mg}$ of nanoparticles in $1 \mathrm{~mL}$ of distilled water was prepared. Then, fresh suspensions with different concentrations of NPs (two fold serial dilutions from 1.56-400 $\mu \mathrm{g} / \mathrm{mL}$ ) were made by means of serial dilution of the stock suspensions of NPs in artificial sea water $(35 \mathrm{~g} / \mathrm{L})$ immediately before use. We added $200 \mu \mathrm{L}$ of a suspension (different concentrations of NPs) to each well of the 96-well microtiter plates. After that, 10 nauplii per well were added in the 96-well plates and incubated at room temperature for $24 \mathrm{~h}$. The numbers of surviving nauplii in each well were counted under a stereoscopic microscope after $24 \mathrm{~h}$. The experiments were conducted in triplicate for each concentration. The negative control wells contained 10 nauplii and artificial sea water only.
The percentages of deaths were calculated by comparing the number of survivors in the test and control wells. The lethality was calculated using Abbott's formula as follows: $\%$ Lethality $=[($ Test - Control $) /$ Control $] \times 100$.

\section{Statistical analysis}

All experiments were done in triplicate and the results were calculated as a mean \pm standard deviation (SD). The experimental data were processed using the paired sample $t$-test, Pearson correlation and linear regression analysis of the SPSS version 16.0 software for Windows. The toxicity of each nanoparticle was calculated from the $50 \%$ lethality dose $\left(\mathrm{LD}_{50}\right)$ by means of Finney's Probit analysis [39].

\section{Results}

\section{Cytotoxicity of nanostructures by the MTT assay}

The MTT assay is a viable method for assessing in vitro cytotoxicity of NPs. In this study, L929 cells were treated with different concentrations $(0.78-200 \mu \mathrm{g} / \mathrm{mL})$ of the 16 NPs (Table 1). Cell viability was determined 24 hours after the treatment. The results are presented in Table 2. Uncoated solid lipid nanoparticles (SLNs), Nanogel + SLN, Bare Nanogel, polyamidoamine (PAMAM; G5), and PAMAM-FA demonstrated moderate cytotoxicity. In contrast, the NPs with $\mathrm{IC}_{50}>200 \mu \mathrm{g} / \mathrm{mL}$ were not toxic to the L929 cell line. The cytotoxicity was weak when the $\mathrm{IC}_{50}$ values were between 150 and $200 \mu \mathrm{g} / \mathrm{mL}$.

\section{Cytotoxicity of nanostructures in the brine shrimp assay}

The brine shrimp lethality assay was also used to determine the cytotoxicity of NPs. According to the results 
Table 2 NPs toxicity assay by Artemia salina and MTT assay

\begin{tabular}{|c|c|c|c|c|c|c|}
\hline \multirow[t]{2}{*}{ NPs name } & \multirow[t]{2}{*}{$\begin{array}{l}\text { Artemia salina } \\
\text { assay, } \mathrm{LC}_{50}(\mu \mathrm{g} / \mathrm{m})\end{array}$} & \multicolumn{2}{|c|}{$\begin{array}{l}95 \% \text { confidence limits for } \\
\text { concentration }\end{array}$} & \multirow[t]{2}{*}{$\begin{array}{l}\text { MTT assay, } \\
\mathrm{IC}_{50}(\mu \mathrm{g} / \mathrm{ml})\end{array}$} & \multicolumn{2}{|c|}{$\begin{array}{l}\text { 95\% confidence limits for } \\
\text { concentration }\end{array}$} \\
\hline & & Lower bound & Upper bound & & Lower bound & Upper bound \\
\hline Magnetic & 698.710 & 431.764 & 2669.870 & 997.402 & 527.931 & 3340.601 \\
\hline Nanosfer & 302.001 & 215.853 & 497.009 & 207.431 & 141.862 & 365.065 \\
\hline Liposome & 751.249 & 432.851 & 6492.955 & 1002.666 & 543.931 & 4358.603 \\
\hline Coated SLNs & 360.594 & 285.519 & 501.000 & 605.594 & 472.900 & 1248.021 \\
\hline Uncoated SLNs & 239.040 & 192.979 & 310.917 & 149.018 & 90.886 & 328.486 \\
\hline Nanogele + SLN & 19.656 & 15.141 & 24.908 & 113.903 & 58.153 & 380.573 \\
\hline Nanogele & 40.440 & 8.221 & 95.196 & 130.171 & 77.672 & 285.277 \\
\hline Micellar & 560.060 & 352.592 & 1801.667 & 686.002 & 263.396 & 1329.851 \\
\hline PAMAM (G5) & 145.6 & 60.435 & 671.764 & 72.254 & 41.149 & 139.077 \\
\hline PAMAM-FA & 213.316 & 185.467 & 839.316 & 99.783 & 61.360 & 130.925 \\
\hline PAMAM-PEG-FA & 401.21 & 256.482 & 1002.310 & 270.585 & 129.042 & 496.556 \\
\hline Nanosuspansion Atorvastatin & 417.349 & 272.658 & 1046.615 & 807.668 & 301.840 & 1080.114 \\
\hline Nanosuspansion Ibuprofen & 373.526 & 285.877 & 559.357 & 156.433 & 117.536 & 244.043 \\
\hline Nanosuspansion Repaglinide & 807.754 & 488.424 & 4335.993 & 297.756 & 221.995 & 527.574 \\
\hline Nanosuspansion Cyclosporin & 531.961 & 368.036 & 1095.239 & 167.965 & 108.493 & 230.459 \\
\hline Nanosuspansion Azitromycin & 110.316 & 57.555 & 231.560 & 162.512 & 168.114 & 249.652 \\
\hline
\end{tabular}

(Table 2), of the 16 NPs that we screened for lethality in A. salina, only two NPs (Nanogel + SLN and Nanogel) showed strong toxicity $\left(\mathrm{LC}_{50}<100 \mu \mathrm{g} / \mathrm{mL}\right)$. In contrast, NPs of Uncoated SLN, PAMAM (G5), Nanosuspension Ibuprofen, and Nanosuspension Azithromycin exhibited moderate cytotoxicity $\left(\mathrm{LC}_{50}\right.$ ranged between 100 and $500 \mu \mathrm{g} / \mathrm{mL}$ ), and the other NPs showed weak cytotoxicity in A. salina $\left(\mathrm{LC}_{50}\right.$ range $\left.500-1000 \mu \mathrm{g} / \mathrm{mL}\right)[37,40]$. Comparison between the results of two methods is indicated in Figure 1. As shown in Figure 1, the trend lines and the direction of the graphs are in same direction.

\section{Discussion}

Several assays for eco-toxicological testing of nanomaterials have been developed. Different model systems such as bacteria [41], fathead minnows [42], zebrafish embryos [43], copepod [44], Daphnia [45,46], and rainbow trout $[47,48]$ have been reported [49]. In addition to standard tests, there is a need to establish better, rapid and convenient methods to predict the toxic effects of nanomaterials. Till now, A few studies have reported the toxicity effect of nanomaterials on A. salina [38,50-52]. These studies were investigated on metal nanoparticles

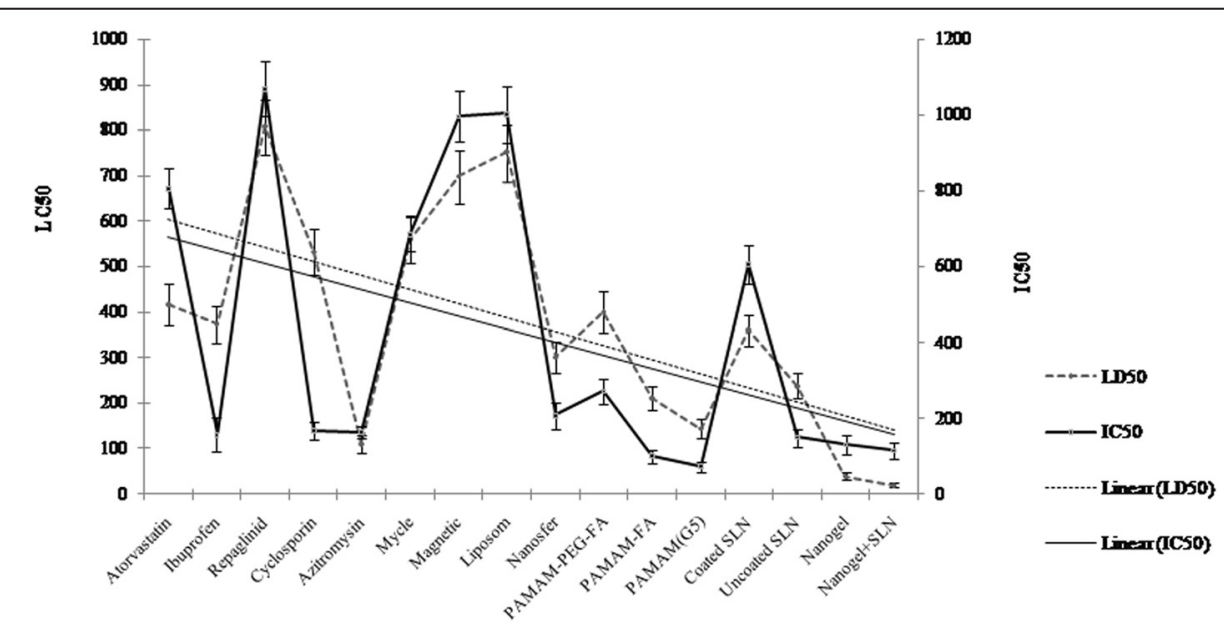

Figure 1 Comparison of Artemia salina and MTT assay results 
and we want develop the A. salina assay for toxicity assessment of different class of nanomaterials especially those used for drug deliveries.

In this work, cytotoxicity of 16 NPs was assessed using two methods: the brine shrimp lethality assay and the MTT assay in L929 cells. According to the results (Figure 1) the correlation between the $\mathrm{LC}_{50}$ and $\mathrm{IC}_{50}$ values is significant $\left(\mathrm{R}^{2}=0.72, P=0.000\right)$. This mean that $72 \%$ variability noted in MTT method could be accounted for by brine shrimp lethality assay and $28 \%$ is unaccounted for due to measurement error. There was not statistically significant difference between two assays when the results were compared with paired $t$ test $(P=0.402)$. Also the comparison between $\mathrm{LC}_{50}$ and $\mathrm{IC}_{50}$ mean values statistically analyzed by chi square test and the result showed that there is no differences between two assay methods $(P=0.235)$. This mean that results obtained by brine shrimp lethality assay is comparable with MTT results. Both the ranking and the degree of cytotoxicity were similar between the brine shrimp lethality assay and the MTT assay. As it has been shown in Table 2, the ranges of $95 \%$ confidence limit are wide. The width of the confidence interval for an individual study depends to a large extent on the sample size. Larger studies tend to give more precise estimates of effects (and hence have narrower confidence intervals) than smaller studies. In order to obtain a more reliable estimate of the confidence interval it may be necessary to perform several independent assays and to combine these into one single confidence interval [53]. The results demonstrate the ability of the brine shrimp lethality assay to accurately quantify cytotoxicity of NPs and to replace the MTT assay, which is expensive and tedious. In this field, cytotoxicity assays and experimental procedures often lack a simple, convenient, and rapid screening method. On the other hand, the brine shrimp lethality assay has been used in toxicology research routinely for over thirty years [36]. The genus Artemia has a several advantages that make it ideal for general toxicity assays including wide geographical distribution, adaptability to extreme conditions, capability to use several nutrient resources, and availability of their cysts for collection [36]. The brine shrimp assay is convenient because it is rapid (24 h), economical, and simple. The eggs of A. salina are readily available at low cost and remain viable for years in dry storage. The assay easily accommodates a large number of nauplii for statistical validation and no special equipment is needed. Moreover, this assay does not require animal serum and thereby it prevents unnecessary use of animals in scientific experiments. In summary, it is possible to measure cytotoxicity of NPs using the brine shrimp lethality assay instead of the common in vitro cell culture assays.

\section{Conclusion}

This work shows that the brine shrimp lethality assay can be used to study toxicity of nanostructures. Self-sufficiency and rapid results are important advantages of this method. Artemia-based toxicity assay of NPs are cheap, continuously available, simple and reliable and are thus an important answer to routine needs of toxicity screening, for industrial monitoring requirements or for regulatory purposes. Our data are expected to facilitate pharmacological and nanotoxicological research.

\section{Competing interests}

The authors declare that they have no competing interests.

\section{Authors' contributions}

SR carried out the experiments and drafted the manuscript. AR designed the study and participated in data analysis. MH participated in study design. TN helped in study design and manuscript preparation. All authors read and approved the final manuscript.

\section{Acknowledgments}

We thank the research deputy of Zanjan University of Medical Sciences (ZUMS) for financial support of this project.

\section{Author details}

${ }^{1}$ Cell and Molecular Biology Departments, Pharmaceutical Sciences Branch, Islamic Azad University, Tehran, Iran. ${ }^{2}$ Biotechnology Departments, School of Pharmacy, Zanjan University of Medical Sciences, Zanjan, Iran. ${ }^{3}$ Zanjan Pharmaceutical Nanotechnology Research Center, Zanjan University of Medical Sciences, Zanjan, Iran.

Received: 6 September 2014 Accepted: 16 February 2015 Published online: 24 February 2015

\section{References}

1. Toumey CP. Reading Feynman into nanotechnology. Techné: Res Philos Technol. 2009;12:133-68.

2. Singh M, Manikandan S, Kumaraguru A. Nanoparticles: a new technology with wide applications. Res J Nanosci Nanotechnol. 2011;1:1-11.

3. Lloyd SM, Lave LB, Matthews HS. Life cycle benefits of using nanotechnology to stabilize platinum-group metal particles in automotive catalysts. Environ Sci Technol. 2005;39:1384-92.

4. Yadav A, Ghune M, Jain DK. Nano-medicine based drug delivery system. J Advanced Pharm Educ Res. 2011;1:201-13.

5. Drobne D. Nanotoxicology for safe and sustainable nanotechnology. Arh Hig Rada Toksikol. 2007;58:471-8.

6. Ikramullah A, Salve D, Pai G, Rathore M, Joshi D. In vitro cytotoxicity testing of silver nano-particals in lymphocyte and sperm cells. Ind J Fund Appl Life Sci. 2013;3:44-7.

7. Arora S, Rajwade JM, Paknikar KM. Nanotoxicology and in vitro studies: the need of the hour. Toxicol Appl Pharmacol. 2012;258:151-65.

8. Sharma A, Madhunapantula SV, Robertson GP. Toxicological considerations when creating nanoparticle-based drugs and drug delivery systems. Expert Opin Drug Metab Toxicol. 2012:8:47-69.

9. Hsieh SF, Bello D, Schmidt DF, Pal AK, Rogers EJ. Biological oxidative damage by carbon nanotubes: fingerprint or footprint? Nanotoxicology. 2012;6:61-76.

10. Wessels A, Van Berlo D, Boots AW, Gerloff K, Scherbart AM, Cassee FR, et al. Oxidative stress and DNA damage responses in rat and mouse lung to inhaled carbon nanoparticles. Nanotoxicology. 2011;5:66-78.

11. Mogharabi M, Abdollahi M, Faramarzi M. Toxicity of nanomaterials; an undermined issue. Daru. 2014;22:59.

12. Mostafalou S, Mohammadi H, Ramazani A, Abdollahi M. Different biokinetics of nanomedicines linking to their toxicity; an overview. Daru. 2013;21:14.

13. Nel A, Xia T, Madler L, Li N. Toxic potential of materials at the nanolevel. Science. 2006;311:622-7.

14. Dhawan A, Sharma V. Toxicity assessment of nanomaterials: methods and challenges. Anal Bioanal Chem. 2010;398:589-605.

15. Maccormack TJ, Clark RJ, Dang MK, Ma G, Kelly JA, Veinot JG, et al. Inhibition of enzyme activity by nanomaterials: potential mechanisms and implications for nanotoxicity testing. Nanotoxicology. 2012;6:514-25. 
16. Suh WH, Suslick KS, Stucky GD, Suh YH. Nanotechnology, nanotoxicology, and neuroscience. Prog Neurobiol. 2009;87:133-70.

17. Dechsakulthorn F, Hayes A, Bakand S, Joeng L, Winder C. In vitro cytotoxicity assessment of selected nanoparticles using human skin fibroblasts. AATEX. 2007;14:397-400.

18. Gonzales M, Mitsumori LM, Kushleika JV, Rosenfeld ME, Krishnan KM. Cytotoxicity of iron oxide nanoparticles made from the thermal decomposition of organometallics and aqueous phase transfer with Pluronic F127. Contrast Media Mol Imaging. 2010;5:286-93.

19. Zanette C, Pelin M, Crosera M, Adami G, Bovenzi M, Larese FF, et al. Silver nanoparticles exert a long-lasting antiproliferative effect on human keratinocyte HaCaT cell line. Toxicol In Vitro. 2011;25:1053-60.

20. Sauer UG, Vogel S, Hess A, Kolle SN, Ma-Hock L, van Ravenzwaay B, et al. In vivo-in vitro comparison of acute respiratory tract toxicity using human $3 \mathrm{D}$ airway epithelial models and human A549 and murine 3T3 monolayer cell systems. Toxicol In Vitro. 2013;27:174-90

21. Decker T, Lohmann-Matthes ML. A quick and simple method for the quantitation of lactate dehydrogenase release in measurements of cellular cytotoxicity and tumor necrosis factor (TNF) activity. J Immunol Methods. 1988;115:61-9.

22. Korzeniewski C, Callewaert DM. An enzyme-release assay for natural cytotoxicity. J Immunol Methods. 1983;64:313-20.

23. Alley MC, Scudiero DA, Monks A, Hursey ML, Czerwinski MJ, Fine DL, et al. Feasibility of drug screening with panels of human tumor cell lines using a microculture tetrazolium assay. Cancer Res. 1988;48:589-601.

24. Campling BG, Pym J, Baker HM, Cole SP, Lam YM. Chemosensitivity testing of small cell lung cancer using the MTT assay. Br J Cancer. 1991;63:75-83.

25. Fisichella M, Dabboue H, Bhattacharyya S, Saboungi ML, Salvetat JP, Hevor $\mathrm{T}$, et al. Mesoporous silica nanoparticles enhance MTT formazan exocytosis in HeLa cells and astrocytes. Toxicol In Vitro. 2009;23:697-703.

26. Silva GA. Introduction to nanotechnology and its applications to medicine. Surg Neurol. 2004;61:216-20.

27. Wang $H$, Cheng $H$, Wang F, Wei D, Wang X. An improved 3-(4,5-dimethylthiazol-2-yl)-2,5-diphenyl tetrazolium bromide (MTT) reduction assay for evaluating the viability of Escherichia coli cells. J Microbiol Methods. 2010;82:330-3.

28. Berridge MV, Herst PM, Tan AS. Tetrazolium dyes as tools in cell biology: new insights into their cellular reduction. Biotechnol Annu Rev. 2005;11:127-52.

29. Costa-Lotufo LV, Khan MT, Ather A, Wilke DV, Jimenez PC, Pessoa C, et al Studies of the anticancer potential of plants used in Bangladeshi folk medicine. J Ethnopharmacol. 2005;99:21-30.

30. Kheiri Manjili H, Jafari H, Ramazani A, Davoudi N. Anti-leishmanial and toxicity activities of some selected Iranian medicinal plants. Parasitol Res. 2012;111:2115-21.

31. Ramazani A, Sardari S, Zakeri S, Vaziri B. In vitro antiplasmodial and phytochemical study of five Artemisia species from Iran and in vivo activity of two species. Parasitol Res. 2010;107:593-9.

32. Ramazani A, Zakeri S, Sardari S, Khodakarim N, Djadidt ND. In vitro and in vivo anti-malarial activity of Boerhavia elegans and Solanum surattense. Malar J. 2010;9:124

33. Sangian H, Faramarzi H, Yazdinezhad A, Mousavi SJ, Zamani Z, Noubarani M, et al. Antiplasmodial activity of ethanolic extracts of some selected medicinal plants from the northwest of Iran. Parasitol Res. 2013;112:3697-701.

34. Mclaughlin JL, Rogers LL, Anderson JE. The use of biological assays to evaluate botanicals. Drug Inf J. 1998;32:513-24.

35. Insanu M, Anggadiredja J, Kayser O. Curcacycline A and B-new pharmacological insights to an old drug. Int J Appl Res Nat Prod. 2012;5:26-34.

36. Nunes BS, Carvalho FD, Guilhermino LM, Van Stappen G. Use of the genus Artemia in ecotoxicity testing. Environ Pollut. 2006;144:453-62.

37. Meyer BN, Ferrigni NR, Putnam JE, Jacobsen LB, Nichols DE, McLaughlin JL. Brine shrimp: a convenient general bioassay for active plant constituents. Planta Med. 1982;45:31-4.

38. Ashtari K, Khajeh K, Fasihi J, Ashtari P, Ramazani A, Vali H. Silica-encapsulated magnetic nanoparticles: enzyme immobilization and cytotoxic study. Int J Biol Macromol. 2012;50:1063-9.

39. Finney DJ. The adjustment for a natural response rate in probit analysis. Ann Appl Biol. 1949;36:187-95.

40. Padmaja R, Arun PC, Prashanth D, Deepak M, Amit A, Anjana M. Brine shrimp lethality bioassay of selected Indian medicinal plants. Fitoterapia. 2002;73:508-10.
41. Lyon DY, Fortner JD, Sayes CM, Colvin VL, Hughe JB. Bacterial cell association and antimicrobial activity of a C60 water suspension. Environ Toxicol Chem. 2005;24:2757-62.

42. Zhu S, Oberdorster E, Haasch ML. Toxicity of an engineered nanoparticle (fullerene, (60) in two aquatic species, Daphnia and fathead minnow. Mar Environ Res. 2006;62(Suppl):S5-9.

43. Zhu X, Zhu L, Li Y, Duan Z, Chen W, Alvarez PJ. Developmental toxicity in zebrafish (Danio rerio) embryos after exposure to manufactured nanomaterials: buckminsterfullerene aggregates (nC60) and fullerol. Environ Toxicol Chem. 2007;26:976-9.

44. Templeton RC, Ferguson PL, Washburn KM, Scrivens WA, Chandler GT. Life-cycle effects of single-walled carbon nanotubes (SWNTs) on an estuarine meiobenthic copepod. Environ Sci Technol. 2006;40:7387-93.

45. Hund-Rinke K, Simon M. Ecotoxic effect of photocatalytic active nanoparticles (TiO2) on algae and daphnids. Environ Sci Pollut Res Int. 2006;13:225-32.

46. Roberts AP, Mount AS, Seda B, Souther J, Qiao R, Lin S, et al. In vivo biomodification of lipid-coated carbon nanotubes by Daphnia magna. Environ Sci Technol. 2007:41:3025-9.

47. Smith CJ, Shaw BJ, Handy RD. Toxicity of single walled carbon nanotubes to rainbow trout, (Oncorhynchus mykiss): respiratory toxicity, organ pathologies, and other physiological effects. Aquat Toxicol. 2007;82:94-109.

48. Fraser TW, Reinardy HC, Shaw BJ, Henry TB, Handy RD. Dietary toxicity of single-walled carbon nanotubes and fullerenes (C60) in rainbow trout (Oncorhynchus mykiss). Nanotoxicology. 2011;5:98-108.

49. Ambrosone A, Marchesano V, Mazzarella V, Tortiglione C. Nanotoxicology using the sea anemone Nematostella vectensis: from developmental toxicity to genotoxicology. Nanotoxicology. 2014;8:508-20.

50. Cornejo-Garrido H, Kibanova D, Nieto-Camacho A, Guzman J, Ramirez-Apan T, Fernandez-Lomelin P, et al. Oxidative stress, cytoxicity, and cell mortality induced by nano-sized lead in aqueous suspensions. Chemosphere. 2011;84:1329-35.

51. Ates M, Daniels J, Arslan Z, Farah 1O. Effects of aqueous suspensions of titanium dioxide nanoparticles on Artemia salina: assessment of nanoparticle aggregation, accumulation, and toxicity. Environ Monit Assess. 2013;185:3339-48.

52. Pretti C, Oliva M, Pietro RD, Monni G, Cevasco G, Chiellini F, et al. Ecotoxicity of pristine graphene to marine organisms. Ecotoxicol Environ Saf. 2014;101:138-45

53. Hong W, Meier $P$, Deininger R. Estimation of a single probit line from multiple toxicity test data. Aquat Toxicol. 1988;12:193-202.

\section{Submit your next manuscript to BioMed Central and take full advantage of:}

- Convenient online submission

- Thorough peer review

- No space constraints or color figure charges

- Immediate publication on acceptance

- Inclusion in PubMed, CAS, Scopus and Google Scholar

- Research which is freely available for redistribution 